\title{
Deconstructing the Struggle Against Nuclearism
}

Prof. Richard A. Falk

Princeton University, USA

\section{Abstract}

In such a complex and uncertain world, it may help to think like a Hindu, and accept contradiction as more in keeping with social and political reality than is finding a right answer to complex policy puzzles. What is almost impossible for those trained within Western frames of reference is to grasp that there are diverse perspectives of understanding that may result in seemingly contradictory recommendations despite shared values and goals. Civilizational perspectives and personal experience inevitably color what we feel, think, and do, and so being likeminded when it comes abolishing nuclear weapons is often coupled with somewhat divergent views on what to advocate when it comes to tactics and priorities.

In this spirit, this paper tries to depict a set of reasons why the goal of nuclear disarmament will never be reached so long as arms control and nonproliferation of nuclear weaponry are seen as the pillars of global stability in the nuclear age. ${ }^{1}$

Keywords: nuclear weapon; nuclear disarmament; United Nations; international law.

\section{Introduction}

Focusing on points of differing policy emphasis and tactical disagreement, does not neccerarly neglect the significance of the similarities that seem more organic and foundational. As I understand these similarities, some main tenets can be identified: the desirability of a world without any nuclear weapons to be pursued by way of an intergovernmental treaty negotiated among the existing nuclear weapons states that achieves nuclear zero by stages of successful implementation, a process formally endorsed by non-nuclear states; such a treaty would unconditionally prohibit possession and further development of the weaponry, reinforce existing prohibitions on threat or use of nuclear weapons, and reduce existing nuclear arsenals by a phased, monitored, verified, and implemented procedures with levels of confidence and ample mechanisms for complaint and dispute-settlement; there are many confidence-building steps that could be taken along the way, either unilaterally or by agreement with other nuclear weapons states, including de-alerting of existing weapons, redefining strategic deterrence doctrine in minimalist and purely defensive terms, and adapting doctrine and deployments in accord with a formally declared adoption of a No First Use Policy, supporting the UN Treaty of Prohibition of Nuclear Weapons (TPNW), which entered into force on January 21, 2021.

\footnotetext{
${ }^{1}$ [For a comprehensive presentation of my approach see Falk, ed. By Stefan. Andersson \& Curt Dahlgren, On Nuclear Weapons:
} Denuclearization, Demilitarization, and Disarmament, 2019. 
Another area of convergence is with respect to the status of nuclear weapons from the perspective of international law. Most advocates of total disarmament, even if arms control friendly, agree that nuclear weaponry is intrinsically unlawful under existing international law, that is, without the desirable reinforcement provided by the TPNW, and that any threat or use of a nuclear weapon would be an international crime for which accountability should attach. Such a consensus affirms the classic dissenting opinion of Judge Christopher Weeramantry in the Advisory Opinion of addressing the legality of nuclear weapons in the International Court of Justice. [See "The Legality of the Threat or Use of Nuclear Weapons," Advisory Opinion, International Court of Justice (1996); see also Shimoda case decided in 1963 by the Tokyo District Court as interpreted, Falk, "The Shimoda Case," American Journal of International Law, Vol. 51, 759-793]

There is also widespread agreement that maintaining confidence in such a denuclearizing world would require the parallel phasing out of nuclear energy capabilities. Nuclear power facilities as themselves too dangerous to be tolerable, despite those that claim their necessity for realistic project to reduce carbon emissions in accord with the scientific consensus. Events such as the accident at Chernobyl or the tsunami that caused the disruption of the Fukushima facilities are illustrative of the dangers arising from accidents and extreme natural events. Nuclear power plants provide targets for political extremists and disposal of nuclear waste pose major health threats. As well, sophisticated nuclear technology is susceptible to dual use, would feed suspicions that could easily cause disenchantment with nuclear disarmament, and give rise to international tensions, even war-threatening crises. The allegations and conflict potential associated with Iran's nuclear program is indicative of the problems that would face a world monitoring and verifying disarmament commitments where a breakout from an agreement would likely cause dangerous reactions in an atmosphere of geopolitical panic.

\section{The Incompatibility of Arms Control and Disarmament}

I have long advocated drawing a sharp distinction between arms control as managerial and geopolitical in its nature and disarmament as transformative and juridical in character. By managerial I mean that the primary purpose of a given measure is to reduce risks posed by and costs associated with the nuclear status quo. Typical arms control proposals involve de-alerting weapons systems, agreeing to forego certain modernizing technologies, avoiding provocative doctrines and deployments, and reducing numbers of warheads and missile launchers.

By geopolitical I reference the fact that the intended and actual goal of most managerial initiatives is to add stability to the nuclear status quo, including not challenging the possession, control, and legitimacy of the weaponry as currently exercised by the main nuclear weapons states. An arms control approach also helps explain the priorities 
accorded to nonproliferation and counter-proliferation policies as in the dealing by the nuclear weapons states alleged to be a supposed nuclear aspirant as Iran or such a pariah state as North Korea. Indeed, in mainstream media and political discourse the challenge of nuclear weaponry is reduced to strengthening, stabilizing, and enforcing the nonproliferation regime, and nuclear disarmament is clearly struck from the policy agenda of the nuclear weapons states.

My view is that the endorsement of arms control approaches subtly and indirectly substitutes management for transformation, and leaves the world facing unacceptable risks of intended and unintended uses of nuclear weapons for the indefinite future, as well as 'the nuclear apartheid' structure of allowing possession, development, and deployment by the nuclear weapons states and prohibiting it for all others. Beyond this, it overlooks the cultural and collective legal/ethical/spiritual (normative) costs associated with deterrence strategies that regard retaliatory uses of nuclear weapons as a legal and ethical security policy despite their indiscriminate, toxic, genocidal, catastrophic, and possibly omnicidal characteristics. [E.P. Thompson, "Notes on Exterminism: The Last Stage of Civilization," New Left Review, May/June, 1980.]

Geopolitical factors are not generally considered in discussions of these issues, but given my world order interests I regard geopolitics as subverting the major premise of state-centric world order, namely, the equality of sovereign states. [UN Charter, Article 2(1): "The Organization is based on the principle of the sovereign equality of all of its members."] Of course, this formulation in the UN Charter is mendacious language that cannot be reconciled with the P-5 permanent membership and right of veto in the Security Council. A prime ingredient of national sovereignty is the unconditional authority of states to determine their own security policy when it comes to selfdefense, especially in response to threats. The irony of the managerial approach is that the two states with the most plausible security justifications for recourse to nuclear deterrence, Iran and North Korea, are the only states under pressure to forego or renounce all intentions of acquiring such weaponry. Even worse, this policy of denial is not a decision of the world community at the UN. It is a self-serving policy articulated by the nuclear weapons states, especially the United States, the UK, and France, geopolitical players that have assumed the role of nuclear gatekeepers while keeping their own nuclear options discretionary and secret. Instead of juridical equality, nuclear weapons policy is geopolitically hierarchical.

I acknowledge that drawing this sharp line between arms control and disarmament has some drawbacks. Perhaps, the most important of these is to make the goals of anti-nuclear activism seem unattainable and utopian because of the weak political will present to challenge the nuclear status quo, a political reality that has persisted since 1945 without any further weapons use. It can be argued in favor of arms control, that its measures are inherently valuable, and raise the anti-nuclear morale by demonstrating 
that concrete steps can be taken to reduce overall risks and costs of nuclearism, that something positive is happening in response to these concerns. Further, that when and if a more peace-oriented political atmosphere emerges, it would be a simple matter to advocate total nuclear disarmament, and on this basis strengthen the political will to encourage political leaders that the time has come to pursue transformative initiatives. In effect, as matters now stand, arms control seems better than nothing, and in this period, it is prudent to get what is possible, while maintaining the expectation that at some time under conditions impossible to anticipate, nuclear disarmament would rise to the top of the political agenda.

I entertain these expectations to a certain extent. I continue to hope that a transformative agenda will at some point (other than a post-catastrophe context) be supported by an insistent public opinion and by responsive political leaders. In the 1990s I had the hope that at the end of the Cold War, especially as coupled with the collapse of the Soviet Union, there would be an irresistible surge of support for seeking nuclear disarmament. After all, political events had undermined the main deterrence rationale for retaining and developing the weaponry, and there seemed no reason to retain such potentially catastrophic weaponry. I thought both leaders and citizens would seize the opportunity to work toward a nuclear-free world. Sadly, it didn't happen, and was not even seriously considered. There was no push from below, and no interest from above. We should all be asking ourselves why such a mood of nuclear complacency prevailed when there seemed so much to gain by working toward an attainable and historic agreement to rid future generations of the fear that somewhere, somehow this infernal weaponry would again wreak havoc. One part of an explanation is that the nuclear dimension of the militarized bureaucracy in the United States, and elsewhere, is sufficiently influential to inhibit any concerted political moves to rid the world of nuclear weaponry.

I want to stress my perception that the driving force behind arms control is to enhance the stability of the nuclear environment and save money. In my view, foregoing certain nuclear innovations and deployments makes nuclear disarmament seem less necessary rather than more attainable. In this regard, arms control falls within the domain of political liberalism, which is itself under attack from neoconservative militarists who regard any international arrangements designed to reduce the risks associated with nuclear weaponry as a snare and delusion, and definitely not in the national security interest of the United States, and maybe some other nuclear weapons states.

Such a mainstream debate on the pros and cons of arms control needs to be understood as most essentially about the managerial form. The geopolitical hawks are arguing in favor of national management of nuclearism with due regard for the pursuit of strategic national interests. Most liberals favor negotiated international management arrangements that limit geopolitical options, including the avoidance of nuclear arms 
races. Arms control liberals also seek to minimize costs and risks of the nuclear status quo, giving a strong priority to keeping the nonproliferation regime alive and well. The most idealistic arms controllers feel that success with partial measures would build confidence of governments needed to take more ambitious denuclearizing steps in the future.

As suggested, my divergence of views with arms control advocates can to some extent be regarded as complementary rather than posing an either/or choice.[Falk/Krieger, Path to Zero; Dialogues on Nuclear Dangers (2016).] I regard it as useful to understand that arms control generally tends to work, at least for the foreseeable future, against rather than in support of nuclear disarmament. I understand Krieger and other nuclear zero advocates to be suggesting that while abolition is the primary goal, during the foreseeable it is desirable to do whatever becomes politically feasible by way of reducing risks and costs associated with the existing nuclear arms environment. This outlook may help explain why some of those dedicated to nuclear disarmament are nevertheless reluctant to make the point that while a given arms control measure may be a constructive contribution in some respects, it has the unacknowledged effect of moving the world further from nuclear disarmament rather than closer to it.

In both positions there is considerable room for convergence. Krieger's position does not oblige him to regard every arms control measure under consideration as beneficial, nor am I committed to rejecting automatically every arms control measure that comes along. For instance, I am aware that we would both favor a declaratory No First Use policy either unilaterally undertaken or adopted by agreement among nuclear weapons states. Contrariwise, we would likely both oppose an international agreement that permitted the development of defense systems that would have the likely effect of making First Strike Options more attractive while claiming to make a rogue surprise attack less likely.

I do feel strongly that we who seek permanent nuclear peace need to understand that the denuclearizing struggle must confront the bipartisan national consensus on these issues in the United States, which has survived without controversy despite the end of the Cold War. The consensus holds that the existing nuclear weapons regime needs to be managed, but never disassembled. The consensus is split as to who should do the managing, and what should be the role of geopolitics in the overall scheme. It regressively excludes from political imagination any endorsement of nuclear disarmament as a matter of principle. The Statement of US, UK, and France expressing their reasons of these governments for rejection of TPNW makes this clear. The main contention of this Statement is that even after the Cold War nuclear weapons enhance national security rather than erode it. By such reasoning, all sovereign states should have a legal entitlement to acquire the weaponry, and hence it becomes reckless for a government not to become a nuclear weapons state, exercising their right of withdrawal from the NPT. 


\section{The Normative Ambiguity of Non-Proliferation and Counter Proliferation Policies}

As earlier indicated, the geopolitical essence of the managerial approach is shaped by the nuclear governmental oligarchs rather than by the world community as problematically represented by the UN. In other settings. I have argued that the weakness of community at the global level makes it unrealistic to expect the UN to be effective or even influential whenever a policy issue collides with geopolitical interests. This difficulty was compounded by vesting veto power in the governments of the first five states to acquire nuclear weapons. In other words when it comes to matters of peace and security geopolitics has been written into the constitutional fabric of the UN System with juridical considerations based on sovereign equality put aside at least so far as the Security Council is concerned.

To achieve a world order bargain, a deal of sort was struck, and incorporated into the text of the NPT. Non-nuclear states would receive the technology needed for what was put forward as a good faith pledge would be written into the treaty obliging the governments of the nuclear weapons states to seek nuclear disarmament through international negotiations, and even more ambitiously, general and complete disarmament. [See Articles IV, VII NPT] This tradeoff was flawed in conception and execution. It was flawed because it was based on vague and unmonitored commitments that were almost impossible to interpret, much less implement. It was flawed in practice by discrimination among states, by facilitating covert acquisition of nuclear weapons by Israel, while waging an aggressive war in Iraq that was partly justified on counter proliferation grounds and subsequently relying on irresponsible coercive diplomacy to threaten Iran and North Korea with potentially grave repercussions.

The fundamental flaw of the approach taken in the NPT became increasingly evident over time. It became clear that the nuclear weapons states without exception were not interested in pursuing nuclear disarmament as policy objectives. Occasionally, politicians would put forward their belief in nuclear disarmament. But it was at best an empty wish that lacked political traction, and at worst was a public relations stunt used to gain a propaganda or partisan advantage.

\section{Should the NPT be repudiated in view of the flagrant breach of Article VI by the nuclear weapons states?}

The issue of nonproliferation is central to my understanding of the challenge of nuclearism. [See Robert J. Lifton \& Richard Falk, Indefensible Weapons: The Legal and Political Case Against Nuclearism (1982)] It is central because the establishment of a nonproliferation regime is what has linked geopolitical interests to the retention of nuclear weapons by a small number of countries, above all the five permanent members of the UN Security Council. It sets these five states apart even in relation to the other four nuclear 
weapons states for whom the weaponry is more closely connected with a more specific search for security, status, and regional influence (Israel, India, Pakistan, and North Korea). I believe it is important to expose these unacceptable geopolitical links between nuclear weaponry, nonproliferation, and world peace and security. Liberal anti-nuclearists are either take no notice of these geopolitical dimensions of nuclear policy, and tend to support the nonproliferation regime based on their assumption that the world becomes that much more dangerous as each new political actor acquires nuclear weapons. To take note of the problem is a far cry from finding a solution.

As with arms control, the policy issue raised by nonproliferation is complicated, defies any dogmatic view, and cannot be resolved by rational analysis or even by recourse to moral and legal considerations. I share the view that any sane person would like to live in a world with as few governments having access to nuclear weapons as possible. Seen in isolation, this is a desirable goal. But just how desirable is nonproliferation policy if other considerations are taken into consideration? Among these considerations is the realization that incentives to seek nuclear disarmament are greatly diminished if the nuclear club can be kept small as it allows the nuclear weapons states to retain their security options and geopolitical status associated with the possession of the weaponry, as well as to threaten other states with annihilation without fearing retaliation.

Another important consideration is the distinction between the nonproliferation treaty instrument (NPT) and the implementation of the treaty by way of the establishment of a nonproliferation regime (NPR) devised by and under the control of the United States, and not the UN. Note that the NPT purports, at least, to be based on the formal equality of states, and supposedly relied on a logic of reciprocity with respect to obligations. The nonproliferation regime, in contrast, proceeds from assumptions of inequality, claiming for nuclear weapons states a responsibility for preventing or even reversing proliferation, while imposing no denuclearizing responsibilities on any nuclear weapons state except possibly North Korea. In this sense, due to geopolitics, nonproliferation rather than denuclearization becomes the operative manner of partially integrating or normalizing the weaponry with respect to world order. This means that geopolitics is given precedence over international law and global justice, and few seem to notice, and even fewer appear to care. By treating nonproliferation as independent from the broader issues of peace and justice, the nuclear policy question is reduced to whether if country $X$ acquires the bomb will the world or region be safer or more dangerous. This kind of reasoning has provided the justification for insisting that Iran demonstrate to the world that it does not possess nuclear weapons, and is not seeking to produce despite its technological capacity and infrastructure that confers the potentiality. Geopolitical prerogatives authorize the nuclear weapons states to overlook the unlawfulness of threats to the security of these potential proliferators that seem to explain their temptations to develop a nuclear weapons capability. 
There are further concerns about burying these issues beneath the banner of national nuclear bipartisanship.[By bipartisanship I am referring to the consensus that has generally transcended party differences in the formulation and carrying out of foreign policy, including adherence to the logic of nuclearism, which includes the management of the counterproliferation regime.] For one thing, the counterproliferation regime tacitly authorizes threats and uses of force to carry out its nonproliferation missions. Such threats and uses of force have been relied upon to uphold to case for attacking and occupying Iraq since 2003 despite the refusal of the UN Security Council to accept the argument or authorize the undertaking. Since this undertaking could not be validated by reference to self-defense as defined in Article 51, it must be considered a violation of the core norm of the UN Charter (Article 2 (4)) and thus appears to qualify as a war of aggression, which was treated as the most severe of international war crimes at the Nuremberg trials held after World War II as well as being a damaging show of disrespect for the authority of the United Nations given that authorization was requested and denied. The same dynamic is at play with regard to Iran at the present time. Threats and sanctions, without any UN authorization have been directed at Iran, a state that seems at the mercy of geopolitical instability, further accentuated by Trump irresponsible repudiation of the Joint Comprehensive Plan of Action (JCPOA) negotiated during Obama's term as president. The main conclusion to be reached is that implementing nonproliferation has been achieved at the expense of international law and even the UN Charter, and by relying on a one-sided interpretation of the NPT that grants impunity to the nuclear weapons states while enacting unlawful punitive measures against non-nuclear states, especially those that are targets of geopolitical enmity. My impression is that advocates of continuing validity of the NPT arrangement are insensitive or ignorant toward this double standard relating to compliance.

A second intrusion by geopolitical manipulation is the manner in which countries outside the P-5 are treated when it comes to nuclear weaponry. It seems evident that Israel was given entry to the club despite its covert means of acquiring the capability, even receiving secret technological assistance from several P-5 nuclear weapons states. Whether by agreement or choice Israel has maintained a formal posture of neither admitting nor denying the existence of its weapons arsenal, although it is widely accepted that it possesses the weaponry and continues with further development activities. [Seymour Hersh, The Samson Option: Israel's Nuclear Arsenal \& American Foreign Policy 1991] What is clear is that the NPR discriminates among states based on their international alignments and size, allowing Israel in, while keeping Iraq and Iran out. This discriminatory practice illustrates the geopolitical tendency to divide the world into friends and enemies when allocating rights and duties among sovereign states. In other words, geopolitical rather than legal criteria are relied upon to establish the policy interface between nuclear haves and have nots. 
A third intrusion is the effect of allowing the NPR to override the treaty without any attempt at reconciling the two sources of normative order, or even to alter the NPT so that it conforms to the practices of NPR. The NPT imposes a solemn obligation on nuclear weapons states to pursue nuclear disarmament in good faith with an intention to conclude an agreement. [See unanimous finding of ICJ in the Nuclear Weapons Advisory Opinion. The language used by the $14-0$ vote, which included the American judge, is suggestive: "There exists an obligation to pursue in good faith and bring to a conclusion negotiations leading to nuclear disarmament in all its aspects under strict and effective international control." The finding in the Advisory Opinion follows closely the wording and spirit of Article VI of the NPT: "Each of the Parties to the Treaty undertakes to pursue negotiations in good faith on effective measures relating to cessation of the nuclear arms race at an early date and to nuclear disarmament, and on a treaty on general and complete disarmament under strict and effective international control."]

These states are parties to the NPT, and yet they have joined in the virtual negation of this most fundamental feature of the treaty text that undoubtedly explains the willingness of most non-nuclear states to become parties to the treaty. We can only speculate as to whether the NPT would have ever come into force without having this reciprocal feature that bound the two states in an encompassing agreement. The NPT seemed to have the intrinsic merit of seeking to rid the world of nuclear weapons by negotiation while freezing nuclear membership. The treaty has been reasonably successful in inhibiting further acquisition of this highly dangerous and legally dubious category of weaponry, while being an unacknowledged failure so far as its reciprocal goal of denuclearization.

In the end, this double standard raises the question as to whether the NPT should be repudiated, or at the very least subjected to sharp criticism by non-nuclear parties. From a legal point of view the nuclear weapons states appear to have violated material provisions of the treaty, giving non-nuclear parties an option to void the agreement. As matters now stand, the NPT provides a legal rationale. for the claims put forward by the NPR. Yet the repudiation of the NPT could be interpreted as a green light to acquisition of the weaponry as an insurance policy. In view of such a dilemma, the best response might be a heightened effort to apply the treaty as drafted, especially insisting on compliance with Article $\mathrm{VI}$, and further construed by seeking a second Advisory Opinion from the World Court.

The NWPT is another sort of pushback against both NPT and NPR, as well. It obviously challenges the legality and legitimacy of the geopolitical nuclear apartheid as pertains to the control of nuclear weaponry by putting forward a treaty seeking a wide-ranging normative prohibition of nuclear weaponry that is applicable to all states. 
Alongside concerns about proliferation is the absence of concern in response to the maneuvers of geopolitics as these bear on the sovereign right of states to uphold their security and to exercise their inherent right of self-defense. Actually, Iran and North Korea have far more reasonable security arguments for acquiring nuclear weapons than do any of the other nuclear weapons states. This recognition does not justify acquiring the weaponry, but it helps explain the reasonableness of their behavior as compared the examples being set by leading states. Such vulnerable states are faced with defending their territorial sovereignty against coercive diplomacy and possible interventions and encroachments on their security carried out and promoted by neighboring political actors controlling vastly superior military forces, and in these instances allied with nuclear weapons states.

By this pronounced unwillingness of the NPR to allow certain states to determine their own security needs if it undermines efforts to prevent further proliferation, unaccountable and often irresponsible geopolitical managers of NPR are effectively given the authority to override national security policy of these weaker states. For instance, Iran is threatened with military attack if it crosses certain technological thresholds. As significant, geopolitical forces make no effort to take steps to reassure Iran with respect to security or to replace a nonproliferation approach by pushing for the establishment of a Middle East Nuclear Free Zone. There has been no response by the West to Iran's president, Hassan Rouhani, who presented a peace plan for the Persian Gulf in 2019 at the UN General Assembly, given the name Hormuz Peace Endeavor with the fitting acronym of HOPE.

The example of Libya haunts this topic of forgoing the nuclear weapons option, as many believe that if Muammar Qaddafi had not abandoned plans to acquire nuclear weapons, he would be alive today. Similarly, if Saddam Hussein had really possessed a stockpile of weapons of mass destruction, many believe that Iraq would never have been attacked in 2003. In other words, nuclear deterrence is possibly a more effective approach to national security if invoked by relatively weaker nuclear states. The NPR offers no compensatory steps to offset security concerns of such obviously vulnerable states as Iran beyond their rather tenuous conditional willingness to remove sanctions, and thus it is not surprising that nonproliferation is tied to militarism.

It is also notable that the most prominent instance in which hawkish foreign policy establishment figures advocated nuclear disarmament was in reaction to their skepticism about the viability of NPR in containing future proliferation. [George P. Shultz, William Perry, Henry Kissinger, and Sam Nunn, "A World Free of Nuclear Weapons," Wall Street Journal, Jan. 4, 2007; see by same authors, "Deterrence in the Age of Nuclear Proliferation," WSJ, March 7, 2011.]. In effect, these geopolitically oriented political figures, influential former holders of high-profile security positions, favored nuclear disarmament not because of any moral scruples or fear of an impending apocalypse, but because of their worries that the NPR was breaking down. 
In effect, their belief that further proliferation would likely occur, and make it so much more difficult to achieve geopolitical political goals that they were uncharacteristically willing to recommend phased denuclearization as a grand strategy. They did this in the belief that the West would enjoy military dominance in a denuclearizing world through their retention of far superior non-nuclear capabilities, which were in any event, more usable in the course of foreign policy if there seemed to be no risk of an unwanted escalation above the nuclear threshold. I believe these complexities need to be discussed, while arms control proponents tend to believe that such issues are often 'academic' distractions that fail to keep the proper focus on what is wrong about the weaponry and how to get rid of the weapons before they get rid of humanity.

\section{Can we have Stage III nuclear disarmament without non-nuclear demilitarization?}

A final issue touched upon is whether a credible posture toward a disarmament process for nuclear weapons must at some stage also address issues relating to nonnuclear demilitarization, and indeed war itself. Arms control oriented thinkers stresses more than I would the distinctive policy priority arising from the acute dangers posed by nuclear war. Those that favor nuclear disarmament stress the obstacles to nuclear disarmament created by existing levels of militarism as well as by the role of war in international relations and as embedded in the political realist mentality that continues to regulate the behavior of national leaders.

There is a practical argument about inducing the weaker nuclear states to enter into a treaty framework that leaves them more vulnerable after giving up their arsenal of nuclear weapons. The governments of such states to the extent that their leaders believe that exposure to hostile states wielding superior conventional weaponry would discourage any effort to tamper with the nuclear status quo. Such security minded states likely include Pakistan, Israel, North Korea, and possibly India (in relation to China).

As a nuclear disarmament process deepened, there would be more attention given to a denuclearizing security environment. To achieve the goal of total abolition, the only acceptable outcome of a denuclearizing process, parallel steps would need to be taken to reduce non-defensive armaments, which might be difficult with the emergence of drones and accurate long-range missile technology.

\section{Concluding Note}

Some anti-nuclear moderates believe that the most promising way to reach a world without nuclear weapons is to convince society that fears of a nuclear war are well-founded, that the results of a war fought with nuclear weapons would be unimaginably horrible in its devastation and aftermath, and that phased, verified 
nuclear disarmament offers a safer and more humane alternative that would give permanent nuclear peace its best chance. [See Daniel Ellsberg, The Doomsday Machine: Confessions of a Nuclear War Planner (2017)]

I do not agree. In contrast, I am convinced that to move forward toward total nuclear disarmament we need to take much better account of the obstacles, frictions, and nuances, explaining why the anti-nuclear movement has so far failed to challenge effectively the nuclear weapons establishment. This position is open to criticism as being overly concerned with obstacles, and less focused on issues of morality, prudence, political action, and war prevention (relating to the implicit arms control claim that nuclear deterrence has prevented all major wars for more than 75 years, including those that might have been fought had nuclear weapons not existed).

In the end, I think we need to continue to have dialogues between those antinuclearists who are uncritical about the friction between pursuing arms control and disarmament, and those who believe that their antagonisms must be addressed. It remains crucial to keep mobilizing moral outrage as the foundation for political action. By contrast, I believe that ant-nuclearism will not get far until it clarifies the tensions between seeking arms control and favoring nuclear disarmament. It seems a serious confusion to suppose that arms control is a halfway house and a serious moral and political failure not to critique the nonproliferation regime that sustains nuclear apartheid which is self-servingly asserted to be the only path to global security. [See George W. Bush, U.S. National Security Strategy, 2002, an important interpretation of global security that fails even to acknowledge nuclear disarmament as a desirable goal].

My assessment of the arms control/disarmament interface can be summarized in a series of propositions:

- that it is morally, legally, politically, and prudentially imperative to rid the world of nuclear weaponry through a verified nuclear disarmament treaty and accompanying implementation regime, and this should be regarded as the paramount goal of anti-nuclearism, taking precedence over other goals;

- that arms control approaches must be explicitly understood as managing nuclear weapons, which is often not consistent with achieving the paramount goal, and may actually make the goal of total nuclear disarmament less attainable;

- that the two top priorities of the managerial approach to nuclear weaponry are to prevent a major war and to prevent further proliferation of nuclear weaponry to additional sovereign states, and especially to those potential nuclear weapons states that have adversary relationship to regional and global geopolitical regimes;

- that despite the NPT, avoiding further proliferation of nuclear weaponry requires reliance on implementation by geopolitical regimes, by threats, and if necessary, by military action; 
- that the coercive maintenance of non-proliferation has produced a structure of nuclear apartheid, which is inconsistent with the world order premise of the equality of sovereign states and will be resisted from time to time by states whose security is under threat or who harbor hegemonic ambitions;

- that the final stages in any disarmament process must also address global militarism in general and reduce non-nuclear military capabilities;

- that overcoming current high levels of complacency about the risks and effects of a nuclear war will depend on civil society activism and a more peace literate public opinion, and will not be achieved by normal diplomacy.

\section{Bibliography}

1. United Nations. General Assembly. Legality of the Threat Or Use of Nuclear Weapons: Request for Advisory Opinion by the General Assembly of the United Nations: Advisory Opinion. International Court of Justice, 1996.

2. Falk, Richard A. "The Shimoda Case: A Legal Appraisal of the Atomic Attacks Upon Hiroshima and Nagasaki (1965)." Am. J. Internat. L. 59: 759.

3. Thompson, Edward. Notes on exterminism, the last stage of civilization. May, 1980.

4. Falk, Richard A., and David Krieger. Path to Zero: Dialogues on Nuclear Dangers. Routledge, 2015.

5. Ferrarotti, Franco. "Science, for What? Or: Science with Conscience-The Invisible College of Dissenting Nuclear Scientists." Academicus International Scientific Journal 10.20 (2019): 12-33.

6. Lifton, Robert Jay, and Richard Falk. "Indefensible weapons: The political and psychological case against nuclearism." (1982).

7. Hersh, Seymour M. "The Samson Option: Israel's Nuclear Arsenal and American." Foreign Policy (1991): 1960-1991.

8. Shultz, George P., William Perry, Henry Kissinger, and Sam Nunn, "A World Free of Nuclear Weapons," Wall Street Journal, 2007

9. Ellsberg, Daniel. The doomsday machine: Confessions of a nuclear war planner. Bloomsbury Publishing USA, 2017.

10. Bush, George W. "The National Security Strategy of the United States of America (Washington, DC: White House, September 2002)." An excerpt from the President's speech dated September 17 (2002). 